\title{
PROCESO METODOLÓGICO PARA LA PLANIFICACIÓN Y EJECUCIÓN DE UNA CAMPAÑA EDUCATIVA PARA INCREMENTAR EL CONSUMO DE FRIJOLES 1
}

\author{
METHODOLOGICAL PROCESS TO PLAN AND IMPLEMENT AN \\ EDUCATIONAL CAMPAIGN TO INCREASE BEAN CONSUMPTION ${ }^{1}$
}

\author{
Ligia Rodríguez ${ }^{2}$, Shirley Rodríguez ${ }^{3}$
}

\begin{abstract}
RESUMEN
Proceso metodológico para la planificación y ejecución de una Campaña educativa para incrementar el consumo de frijoles. El presente trabajo describe la planificación de una Campaña educativa para incrementar el consumo de frijoles y las acciones desarrolladas durante la ejecución de la misma. Permite, al mismo tiempo, dimensionar los aportes del diagnóstico previo y los resultados de la evaluación. Finalmente, el artículo resume las "lecciones aprendidas" durante el desarrollo de estas dos etapas y aporta consideraciones sobre su importancia y aplicabilidad. También se incluyen algunas otras "lecciones aprendidas" que corresponden a todo el proceso.
\end{abstract}

Palabras claves: Campaña educativa, planificación, ejecución, frijoles.

\begin{abstract}
Methodological process to plan and implement an educational Campaign to increase bean consumption. This article describes planning of an educational Campaign to increase bean consumption, and the activities carried out during its implementation. At the same time, it highlights the contributions of an initial assessment and the result of the final evaluation. Finally, the article summarizes the "lessons learned" during implementation of these two phases, and provides considerations about their importance and applicability. Other "lessons learned" throughout the process are also included.
\end{abstract}

Key words: educational Campaign, planning, implementation, beans.

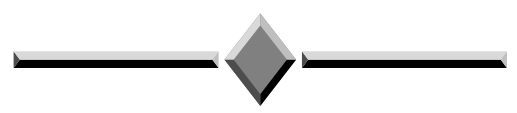

\section{INTRODUCCIÓN}

La participación de la población en los esfuerzos por resolver los problemas que los afectan, es una necesidad reconocida. Esta participación es particularmente importante al realizar acciones de educación nutricional, porque las conductas en las cuales se pretende incidir

1 Recibido para publicación el 25 de junio del 2004. Este artículo se deriva de la investigación desarrollada en el "Proyecto Campaña Educativa para Incrementar el Consumo de Frijoles", de la Escuela de Nutrición de la UCR, inscrito dentro del proyecto macro "Mejoramiento de la Digestibilidad del Frijol", CITA-UCR, bajo el auspicio del Programa Bean/Cowpea CRSP; USAID Grant DAN-G-SS-86-0008-88.

2 Escuela de Nutrición, Universidad de Costa Rica. Investigadora principal del "Proyecto Campaña Educativa para Incrementar el Consumo de Frijoles". E-mail: farodri@ racsa.co.cr

3 Universidad de Costa Rica, Escuela de Nutrición.

\section{INTRODUCTION}

People's participation in the efforts carried out to solve the problems that affect them is an acknowledged necessity. This participation is particularly important when implementing nutritional education actions, because the behaviors to be modified may be deeply

\footnotetext{
1 Received for publication on June 25, 2004. This article is the result from the investigation carried out in the Project "Educational Campaign to Increase Bean Consumption", from the University of Costa Rica's Nutrition School, which is part of the macroproject "Improving Digestibility of Beans", CITA, UCR, sponsored by the Bean/Cowpea CRSP Program; USAID Grant DAN-G-SS-86-0008-88.

2 University of Costa Rica, Nutrition School. Principal Researcher Project "Educational Campaign to Increase Bean Consumption". e-mail: farodri@ racsa.co.cr

3 University of Costa Rica, School of Nutrition.
} 
pueden estar profundamente arraigadas en el contexto socio-cultural de la población (FAO 1996). Por otra parte, ningún medio de comunicación que se utilice, puede por sí solo influir significativamente en dicho contexto y consecuentemente en los hábitos alimentarios (Adrien 1994).

Para que la educación nutricional tenga efectos positivos debe fundamentarse en un diagnóstico previo, establecer nexos con la comunidad y otros actores sociales y utilizar diversos medios y canales. Esto requiere de una planificación detallada que además, defina con claridad los objetivos educativos.

El proceso que se describe en el presente artículo corresponde a un esfuerzo educativo que desarrolla la Escuela de Nutrición de la Universidad de Costa Rica, por medio de un proyecto denominado Campaña Educativa para Incrementar el Consumo de Frijoles. Dicho proyecto tiene como propósito contribuir a contrarrestar la disminución en el consumo de frijoles que se ha detectado en la población urbana costarricense (INCAP/ICNND/ Ministerio de Salubridad Pública de Costa Rica 1969, Ministerio de Salud, 1996). Esta disminución podría responder al cambio de patrones alimentarios que se observa en los procesos de urbanización (Peña y Bacallao 2000, Albala y Vío 2000), lo cual tiene efectos negativos en la alimentación y la nutrición de las poblaciones urbanas.

En la Campaña educativa arriba mencionada, la planificación parte de un diagnóstico previo que involucra desde el principio a la población y considera los otros aspectos arriba señalados.

En un artículo global sobre el proyecto (Rodríguez 2004) se hace una descripción de las diferentes etapas de la Campaña. En el presente trabajo se profundiza en las etapas de planificación y ejecución porque constituyeron el núcleo o eje central de la Campaña. Por eso este artículo se propone describir estas etapas, a fin de dar a conocer lo que se hizo y dimensionar los esfuerzos del diagnóstico y la evaluación.

\section{Metodología de la etapa de planificación de la Campaña}

En el Esquema 1, se presenta un flujograma simplificado del proceso de planificación, que finaliza con la ejecución de la Campaña. Como se observa, a partir del diagnóstico (Campos et al. 1999; Rodríguez y Rodríguez 2003; Rodríguez y Murillo 2004; Murillo y Rodríguez 2004), (complementado con las pruebas de comportamiento (Dumani y Rodríguez 2004)) y del plan de comunicación (Martínez et al. 2000; Páez y Rodríguez 2004), se hizo una propuesta preliminar de "Planificación de la Campaña". rooted into their socio-cultural context (FAO 1996). On the other hand, there is not any communication means that, if used by itself, could possibly have a significant effect on such context and thus, on alimentary habits (Adrien 1994).

In order for nutritional education efforts to have positive effects, they must be based on a previous assessment, they must also establish relationships with the community and other social actors, and use diverse communication means and channels. This requires detailed planning which would also clearly define the educational objectives.

The process described in the present article deals with an educational efford that was carried out by the Nutrition School of the University of Costa Rica, through the Project "Educational Campaign to increase bean consumption". The purpose of this project is to help counterbalance the reduction in bean consumption that has been detected in the Costa Rican urban population ((INCAP/ICNN/Ministerio de Salubridad Pública de Costa Rica 1969, Ministerio de Salud 1996). Such reduction might be a response to the change in alimentary patterns often observed in urbanization processes (Peña and Bacallao 2000, Albala and Vio, 2000), having negative effects on the nutrition of urban populations.

Planning for this Campaign started from an initial assessment, where the population was involved from its very beginning, and takes into account the other aspects mentioned before.

There is a comprehensive article about the Project (Rodríguez 2004) which describes the different phases of the Campaign. In this article, an in-depth analysis is made of the planning and implementation phases, given that they were its core or central components. This article describes these phases, in order to disseminate the work carried out and highlight the importance of the initial assessment and the final evaluation.

\section{Methodology for the Campaign's planning phase}

Diagram 1 is a simplified flowchart of the planning process, which ends with the Campaign's implementation. As may be noted, a preliminary proposal for the "Campaign's Plan" was based on an initial assessment (Campos et al. 1999; Rodríguez and Rodríguez 2003; Rodríguez and Murillo 2004; Murillo and Rodríguez 2004) (complemented by the "behavior tests" (Dumani and Rodríguez 2004)), and the communication plan (Martínez et al. 2000; Rodríguez y Páez 2004). 


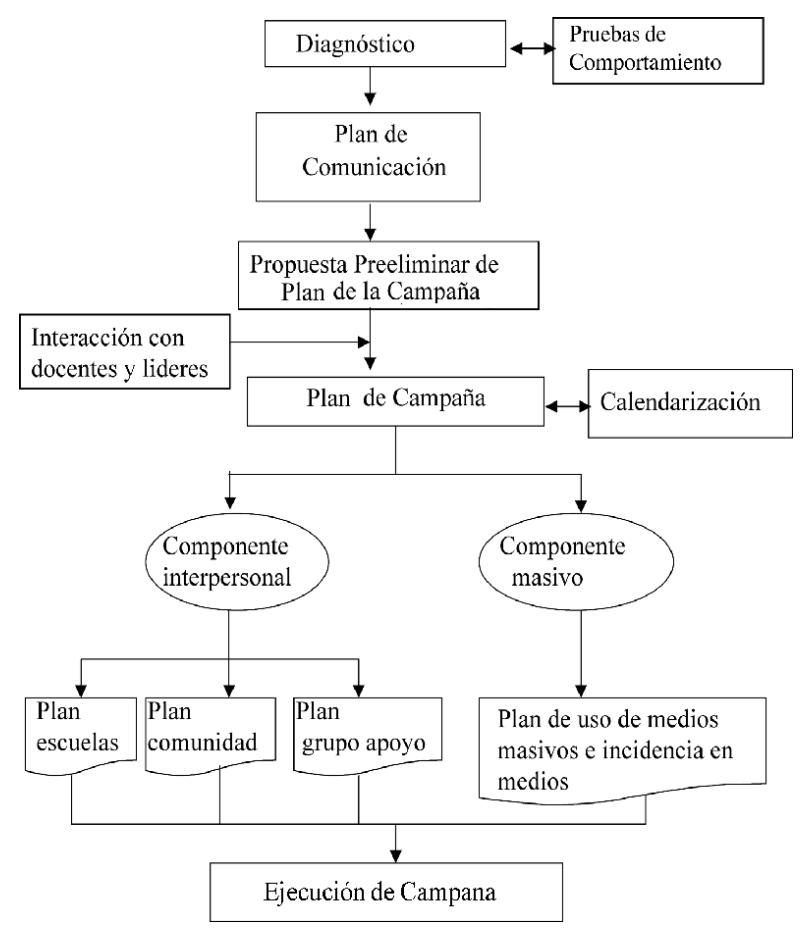

Esquema 1. Flujograma del proceso que lleva a obtener el plan de Campaña y su ejecución. Campaña educativa para incrementar el consumo de frijoles. Sabanilla de Montes de Oca, Costa Rica, 2000.

Los objetivos de la propuesta, que se mantuvieron en el plan definitivo fueron:

General: Incrementar el consumo de frijoles en la población (el cual coincide con el objetivo fijado para todo el proyecto).

Específicos: a) Informar a la población sobre los beneficios del consumo de frijoles; b) Formar a la población sobre las técnicas adecuadas de preparar, consumir y conservar los frijoles y c) Neutralizar las barreras que interfieren con el consumo de frijoles.

Con las recomendaciones de los docentes, el equipo investigador elaboró un plan preliminar, el cual fue presentado y discutido con los líderes comunales.

La escuela constituía un espacio indispensable para establecer contacto con los y las escolares, el personal del comedor y los maestros (as). Una reunión con el personal docente, permitió definir las actividades a ser desarrolladas en ese ámbito y su correspondiente calendarización. Los maestros propusieron el desarrollo de actividades con los niños (as) que implicaran "aprender-haciendo", tales como: preparación de recetas, trabajos de investigación extraclase, elaboración de

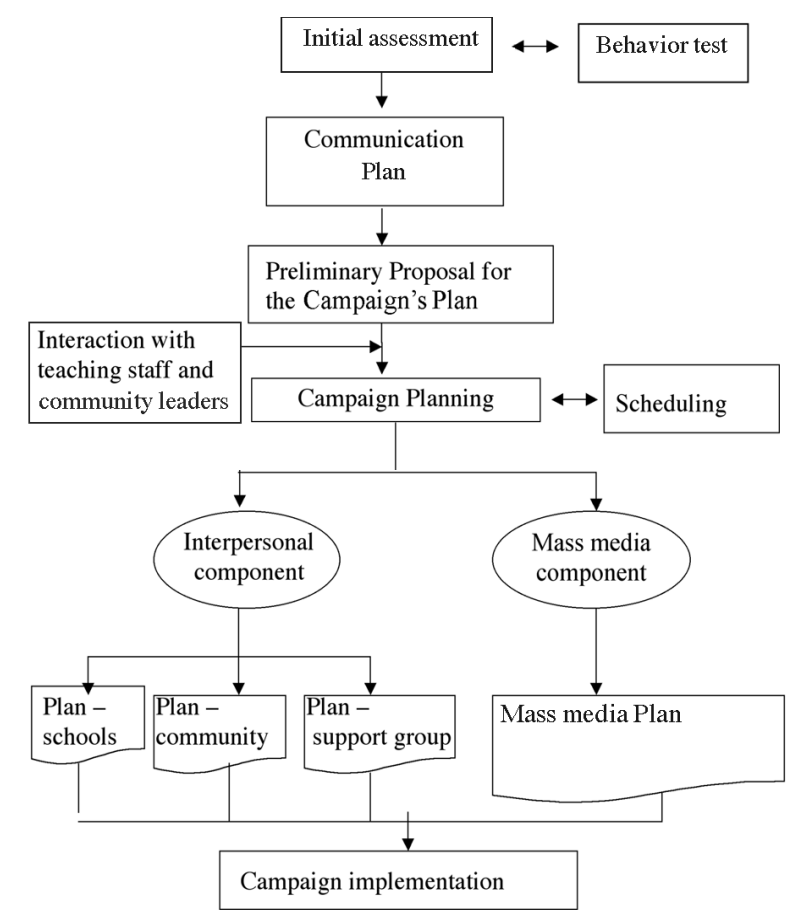

Diagram 1. Flowchart of process to draw up the Campaign's plan and implementation. Educational Campaign to increase bean consumption. Sabanilla de Montes de Oca, Costa Rica, 2000.

The objectives of the proposal, which were kept for the final plan were:

General objective: Increase bean consumption in the population (which is the same as the objective set forth for the overall Project).

Specific objectives: a) Inform the population about the benefits of bean consumption; b) Instruct the population on the adequate ways to prepare, consume and preserve beans; and c) Counterbalance the barriers that hinder bean consumption.

Based on recommendations from the local teaching staff, research team members designed a preliminary plan, which was presented to community leaders, and discussed with them.

Schools constituted an essential space to establish contact with school children, student lunch room staff, and teachers. The schedule and activities to be carried out in that context were arranged through a meeting with the teaching staff. Teachers proposed the implementation of "learning by doing" activities with children, such as: preparation of recipes, after-school research assignments, creation of collages with beans, 
"collage" con frijoles y dibujos con mensajes alusivos. Los líderes comunales, hicieron contribuciones de utilidad sobre la forma de convocar e informar a la población, así como para definir la calendarización de actividades en la comunidad.

Como resultado del proceso anteriormente descrito, se obtuvo el plan de Campaña definitivo con su correspondiente calendarización. Dicho plan, consta de un componente interpersonal y otro de comunicación masiva, los que se concretaron en planes de trabajo para: la comunidad, la escuela y el personal de apoyo (básicamente personal de salud) y en un plan de comunicación masiva e incidencia en medios.

Aunque las madres de los escolares, constituían el grupo objetivo de la Campaña, el diagnóstico había indicado que era muy difícil encontrar espacios de reunión con ellas. En la etapa de planificación hubo que considerar esta limitación y buscar abordajes alternativos. La comunicación masiva se realizó por medio de materiales escritos especialmente diseñados para las madres y los escolares. Dichos materiales se expusieron en varios lugares o se enviaron a las madres. La incidencia en medios a través de la radio, la prensa y la televisión, aunque alcanzaba a toda la comunidad, también se orientó específicamente hacia las madres y los niños (as).

El diagnóstico ofrecía información detallada sobre los medios de comunicación preferidos y de mayor audiencia del grupo objetivo pero, debido a limitaciones presupuestarias, solo era posible satisfacer parcialmente esas preferencias. Por lo tanto, al planificar este componente, fue necesario considerar dichas limitaciones.

En el Cuadro 1 se presenta el formato utilizado para estructurar cada uno de los planes de trabajo y un ejemplo parcial del contenido del plan de trabajo en las escuelas.

Como se observa, cada plan de trabajo se estructuró en siete columnas. En la primera columna se definió la actividad en forma general y en la segunda, se estableció la población meta o audiencia. En las siguientes columnas se retomaron los objetivos y los mensajes del plan de comunicación y se detalló el tipo de actividad y el lugar en el cual se desarrollarían. Finalmente se definieron los materiales que se requerían para esa actividad particular y se señalaron, "los grupos responsables".

Adicionalmente, en un cronograma, se detallaron las tareas que correspondían a cada actividad, los responsables particulares de cada tarea y la calendarización. Este cronograma constituyó un instrumento complementario, de gran utilidad para la ejecución de las actividades. and drawings with suggestive messages. Community leaders made useful contributions on the ways to invite and inform the population, as well as for the schedule of activities in the community.

A final Campaign plan and schedule were the results of the above described process. The plan has two components: interpersonal communication and mass communication, that were carried out through work plans designed for the community, the school, and the support personnel (basically health care personnel), and through a mass media communication plan.

While the mothers of school children were the Campaign's target group, the initial assessment had indicated that it was very difficult to find a space to meet with them. This limitation had to be considered within the plan, and it was necessary to find alternative ways to reach them. Mass communication was carried out by means of written materials which were designed to reach mothers and school children, and were displayed in different locations, or sent to the mothers. Presence in the mass media, which reached the whole community, was aimed at mothers and children.

Messages were broadcast using radio, newspapers, and television. The initial assessment provided detailed information about the mass media preferred by the target group but, due to budgetary constraints, it was not possible to cover all of those preferences. This was another limitation that had to be considered when planning this component.

Table 1 shows the format used to structure each work plan, and a partial example of the content of the work plan for schools.

As may be noted, each work plan was arranged into seven columns. Activities were defined in general terms in the first column, while the target population or audience was specified in the second one. In the following columns the objectives and messages were drawn up based on the communication plan, and the type of activity and place where it would be implemented were specified. Finally, the materials required for that particular activity were defined, and the "groups in charge" were indicated.

In addition, the corresponding tasks, groups in charge, and schedule for each activity were specified in a chronogram, which constituted a complementary instrument that was greatly useful to implement the activities.

Parallel to planning, there were efforts made to obtain complementary financing, establish strategic 
Cuadro 1. Parte del plan de trabajo en las escuelas seleccionadas. Campaña Educativa para Incrementar el Consumo de Frijoles. Sabanilla de Montes de Oca, Costa Rica, 2000.

\begin{tabular}{|c|c|c|c|c|c|c|}
\hline Actividad & Audiencia & Objetivos & Mensajes * & $\begin{array}{c}\text { Tipo de actividad y } \\
\text { Ubicación }\end{array}$ & Materiales & Responsables \\
\hline 1. Motivación & $\begin{array}{ll}\text {-Niños (as) } & \text { de } \\
\text { edad escolar } & \text { (de } \\
\left.3^{\circ} \text { y } 4^{\circ} \text { grado }\right) & \end{array}$ & $\begin{array}{l}\text { 1. Fomentar la } \\
\text { participación y el } \\
\text { apoyo de los niños } \\
\text { (as) en las diferen- } \\
\text { tes actividades de } \\
\text { la campaña. }\end{array}$ & De motivación & $\begin{array}{l}\text { Sesión interactiva } \\
\text { en las aulas. }\end{array}$ & $\begin{array}{l}\text {-Transparencias } \\
\text { - Dibujos } \\
\text { - Lápiz de color }\end{array}$ & $\begin{array}{l}\text { Equipo de trabajo } \\
\text { y asistentes del } \\
\text { proyecto }\end{array}$ \\
\hline $\begin{array}{l}\text { 2. Tarea sobre } \\
\text { "Importancia del } \\
\text { consumo de frijo- } \\
\text { les" }\end{array}$ & $\begin{array}{l}\text { - Niños (as) de } \\
\text { edad escolar (de } 3^{\circ} \\
\text { y } 4^{\circ} \text { grados) }\end{array}$ & $\begin{array}{l}\text { 1. Obtener un le- } \\
\text { ma para la campa- } \\
\text { ña con niños (as). } \\
\text { 2. Retroalimentar } \\
\text { la investigación. } \\
\text { 3. Aumentar el co- } \\
\text { nocimiento de los } \\
\text { niños (as)con res- } \\
\text { pecto a la impor- } \\
\text { tancia del consu- } \\
\text { mo de frijoles. }\end{array}$ & $\begin{array}{l}\text { - De motivación } \\
\text { e información }\end{array}$ & $\begin{array}{l}\text { Coordinación con } \\
\text { maestras de } 3^{\circ} \text { y } 4^{\circ} \\
\text { grado para asigna- } \\
\text { ción de tarea en: } \\
\text { a) Escuela José } \\
\text { Figueres Ferrer. } \\
\text { b) Escuela Mon- } \\
\text { terrey } \\
\text { c) Centro Educativo } \\
\text { Campestre. }\end{array}$ & $\begin{array}{l}\text { - Tarea y bases } \\
\text { para su califica- } \\
\text { ción }\end{array}$ & $\begin{array}{l}\text { Equipo de trabajo } \\
\text { y asistentes }\end{array}$ \\
\hline 3. Teatro & $\begin{array}{l}\text { - Niños (as) de } \\
\text { edad escolar (de } \\
3^{\circ} \text { y } 4^{\circ} \text { grado) }\end{array}$ & $\begin{array}{l}\text { 1. Lograr una } \\
\text { identificación de } \\
\text { los niños con la } \\
\text { campaña }\end{array}$ & $\begin{array}{l}\text { - De motivación } \\
\text { y formación }\end{array}$ & $\begin{array}{l}\text { Taller de teatro en: } \\
\text { a) Escuela José } \\
\text { Figueres Ferrer. } \\
\text { b) Escuela } \\
\text { Monterrey } \\
\text { c) Centro Educativo } \\
\text { Campestre. }\end{array}$ & - Guión & $\begin{array}{l}\text { Equipo de trabajo } \\
\text { y asistentes }\end{array}$ \\
\hline
\end{tabular}

Fuente: Planificación de la Campaña educativa para incrementar el consumo de frijoles. In: Rodríguez, L., Dumani, M., Páez, P e Ivankovich, C. (2002). Informe de julio 2002, del proyecto "Campaña educativa para promocionar el consumo de frijoles en una comunidad urbana".

*Los mensajes específicos se encuentran en la publicación de Martínez et al. (2000).

Paralelo a la planificación, se realizaron gestiones para la consecución de financiamiento complementario, el establecimiento de alianzas estratégicas y la selección y orientación del personal que estaría a cargo de desarrollar diferentes acciones durante la etapa de ejecución. Además, se elaboraron y probaron los materiales audiovisuales que se requerirían en la ejecución de la Campaña.

\section{Metodología de la etapa de ejecución de la Campaña}

Esta etapa comprendió tanto el desarrollo de las actividades planificadas, como el correspondiente monitoreo o seguimiento de las mismas.

El plan de la Campaña fue utilizado inicialmente como una guía para coordinar con los diferentes entes partnerships, and select and train the personnel in charge of carrying out different tasks during implementation. In addition, the audiovisual materials required for the Campaign were prepared and tested.

\section{Methodology for the Campaign's implementation phase}

This phase covered implementation and monitoring of planned activities.

The plan for the Campaign was initially used as a guideline to coordinate with the different participating entities and groups, and to request printing of audiovisual materials required during Campaign implementation. 
Table 1. Part of the work plan for schools. Educational Campaign to increase bean consumption. Sabanilla de Montes de Oca, Costa Rica, 2000.

\begin{tabular}{|c|c|c|c|c|c|c|}
\hline Activity & Audience & Objectives & Messages * & $\begin{array}{l}\text { Type of activity } \\
\text { and place }\end{array}$ & Materials & $\begin{array}{l}\text { Responsible } \\
\text { groups }\end{array}$ \\
\hline 1. Motivation & $\begin{array}{l}\text {-School children } \\
\text { (of } 3^{\text {rd }} \text { and } 4^{\text {th }} \\
\text { grades) }\end{array}$ & $\begin{array}{l}\text { 1.Promote } \\
\text { children's partici- } \\
\text { pation and support } \\
\text { in the different } \\
\text { activities of the } \\
\text { Campaign }\end{array}$ & Motivational & $\begin{array}{l}\text { Interactive } \\
\text { classroom sessions }\end{array}$ & $\begin{array}{l}\text { - Slides } \\
\text { - Drawings } \\
\text { - Coloring pencils }\end{array}$ & $\begin{array}{l}\text { Work team and } \\
\text { Project assistants }\end{array}$ \\
\hline $\begin{array}{l}\text { 2. Homework on } \\
\text { the "Importance } \\
\text { of bean con- } \\
\text { sumption", }\end{array}$ & $\begin{array}{l}\text { - School children } \\
\text { (of } 3^{\text {rd }} \text { and } 4^{\text {th }} \\
\text { grades) }\end{array}$ & $\begin{array}{l}\text { 1.Draw up a } \\
\text { slogan for the } \\
\text { Campaign with } \\
\text { children } \\
\text { 2.Obtain feedback } \\
\text { for the research } \\
\text { 3. E n h a n c e } \\
\text { children's know- } \\
\text { ledge with regards } \\
\text { to the importance } \\
\text { of bean consump- } \\
\text { tion. }\end{array}$ & \begin{tabular}{|l|} 
- Motivational \\
and informatio- \\
nal
\end{tabular} & 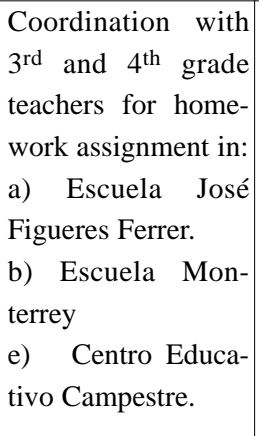 & $\begin{array}{l}\text { - Homework and } \\
\text { grounds for its } \\
\text { grading }\end{array}$ & $\begin{array}{l}\text { Work team and } \\
\text { assistants }\end{array}$ \\
\hline $\begin{array}{l}\text { 3.Theater } \\
\text { workshop }\end{array}$ & $\begin{array}{l}\text {-School children } \\
\text { (of } 3^{\text {rd }} \text { and } 4^{\text {th }} \\
\text { grades) }\end{array}$ & $\begin{array}{l}\text { 1. Get children } \\
\text { identified with } \\
\text { the Campaign }\end{array}$ & 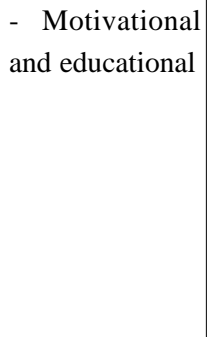 & $\begin{array}{l}\text { Theater workshop } \\
\text { in: } \\
\text { a) Escuela José } \\
\text { Figueres Ferrer. } \\
\text { b)Escuela Monte- } \\
\text { rrey } \\
\text { e) Centro Educativo } \\
\text { Campestre. }\end{array}$ & - Script & $\begin{array}{l}\text { Work team and } \\
\text { assistants }\end{array}$ \\
\hline
\end{tabular}

Source: Planning of the educational Campaign to increase bean consumption In: Rodríguez, L., Dumani, M., Páez, P and Ivankovich, C. (2002). July 2002 Project report of "Educational Campaign to increase bean consumption in a urban community" .

* The specific messages are found in Martínez et al (2000).

y grupos involucrados y para ordenar la impresión del material audiovisual que se requería durante la ejecución de la Campaña.

En el plan se consideró un periodo de tres meses de campaña intensiva, tanto interpersonal como masiva, a ser desarrollada en forma simultánea. Sin embargo, la Campaña debió ampliarse por tres meses más, debido a atrasos en la transmisión de los mensajes radiales y a que los Equipos Básicos de Atención Integral en Salud (EBAIS) de la comunidad de Sabanilla no se habían establecido 4 . Por lo tanto, los primeros tres meses de Campaña fueron de mayor contacto con la comunidad y los otros tres se focalizaron más en el componente de comunicación masiva. Esa extensión del tiempo contribuyó a

\footnotetext{
${ }^{4}$ En enero del 2001 se establecieron los EBAIS en Sabanilla.
}

A three-month intensive campaign to be carried out simultaneously at interpersonal and mass levels was considered within the plan. However, the Campaign had to be extended for three more months due to delays in radio broadcasts, and because the EBAIS $^{4}$ (Basic Health Care Teams) of the community of Sabanilla were not yet established . Consequently, during the first three months of the Campaign there was more contact with the community, while the other three months were mostly focused on the mass communication component. The time extension enabled team members to carry out other activities that had not been planned but were important to achieve the objectives, but limited the intensive approach that had been initially planned.

${ }^{4}$ EBAIS were established in Sabanilla in January 2001. 
que se realizaran algunas otras actividades no planificadas, que eran importantes para el logro de los objetivos, pero limitaron el abordaje intensivo inicialmente planificado.

Otros ajustes al plan se introdujeron durante la etapa de ejecución, como resultado del monitoreo que se realizó. Por ejemplo, se cambió la ubicación de los puestos promocionales en los supermercados. El artículo de Dumani y López (2004), describe esos ajustes.

En el Esquema 2 se visualizan las actividades desarrolladas durante la etapa de ejecución de la Campaña, dirigidas a las diferentes audiencias.

Como ya se mencionó, el grupo objetivo de la Campaña fueron las madres de escolares. La mayor parte del abordaje a este grupo se realizó indirectamente, a través de medios masivos y con actividades que llegaron a toda la población, los escolares y el personal de apoyo. En el esquema, las flechas que parten de los otros grupos hacia el grupo de las madres, indican esa focalización. La única actividad que se dirigió específicamente a las madres fue la entrega de materiales.

Para motivar la participación de las madres en las actividades interpersonales que se realizaban para toda la comunidad, se les enviaron invitaciones personales con los niños (as). En el caso de la comunicación masiva, los mensajes emitidos por los diferentes medios

\section{ACTIVIDADES}

- Feria del frijol y la salud

- Puestos promocionales

- Exposición de afiches

- Cuñas radiales y radioteatros

- Espacios en prensa y TV

- Entrega de recetarios y despegables

- Charlas y demostraciones

- Elaboración de carteles

- Taller de teatro

- Exposición de afiches

- Sesiones de discusión

- Mesa redonda

- Reuniones

- Sesiones demostrativas

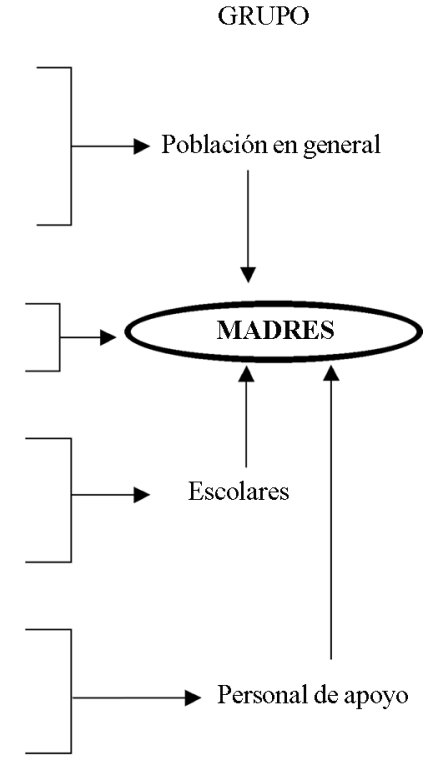

Esquema 2. Actividades desarrolladas. Campaña educativa para incrementar el consumo de frijoles. Sabanilla de Montes de Oca, Costa Rica, 2000-2001.
Other changes to the plan had to be made during implementation, as a result of monitoring. For instance, the location of the promotional stands in the supermarkets was changed. The article by Dumani and López 2004, describes these changes.

The activities involved in Campaign implementation, aimed at the various audiences are shown in Diagram 2.

As mentioned before, the Campaign's target group were the mothers of school children. Most of the approaches to this group were made indirectly, through mass media and activities that reached the overall population, the school children, and the support personnel. In the diagram, the arrows that go from the other groups to the group of mothers indicate that focalization. The only activity directed specifically to the mothers was the distribution of materials.

In order to encourage mothers to participate in interpersonal activities that were held for the whole community, personal invitations were sent to them with their children. In the case of mass communication, the messages disseminated through the different media were designed according to the preferences shown by mothers. Besides, inasmuch as it was possible, the TV channels and radio programs to which they had more access were used.

\section{ACTIVITIES}

- Health and bean fair

- Promotional stands

- Poster displays

- Radio and radio-play spots

- Press and TV advertising

- Recipe book and brochure hand-outs

- Talks and displays

- Poster making

- Theater workshop

- Poster displays

- Discussion sessions

- Roundtable

- Meetings

- Demonstrating sessions
GROUP

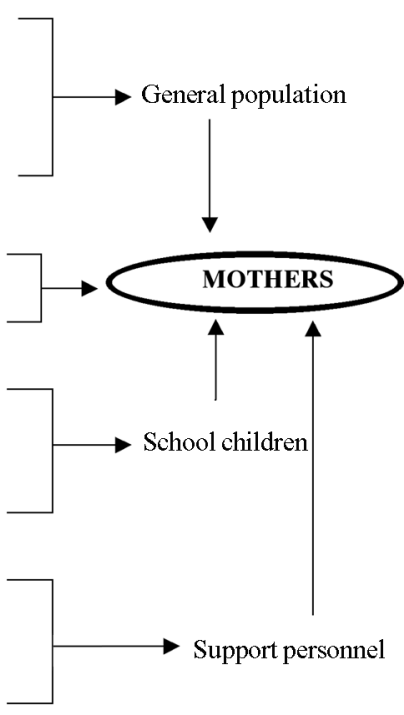

Diagram 2. Activities Implemented. Educational Campaign to Increase Bean Consumption. Sabanilla de Montes de Oca, Costa Rica, 2000-2001. 
fueron diseñados de acuerdo a los gustos y preferencias de las madres. Además, siempre que fue posible, se utilizaron aquellos canales televisivos y programas radiales a los que ellas tenían mayor acceso.

A continuación se hace una breve descripción de las actividades desarrolladas durante la ejecución de la Campaña.

\section{a. "Feria del Frijol y la Salud"}

Para motivar la asistencia, la feria no solo comprendió actividades sobre frijoles, sino también sobre salud en general. Las actividades específicas sobre frijoles que se desarrollaron fueron: degustación de recetas, charlas, puestos de exhibición y venta de frijoles. También una exposición de carteles elaborados por los escolares utilizando frijoles.

Una actividad complementaria, desarrollada por iniciativa de los docentes, fue la asignación de una tarea a los escolares sobre los frijoles. Esto resultó positivo, ya que motivó una actitud más participativa en la Feria de parte de los niños (as) y de las madres.

\section{b. Puestos promocionales}

Esta intervención se llevó a cabo en los supermercados más frecuentados por la población de Sabanilla. En esta actividad, se entregó a los clientes información escrita y verbal y se les ofreció la degustación de preparaciones no tradicionales a base de frijoles.

\section{c. Medios masivos de comunicación}

Por el costo de los espacios en los medios masivos de comunicación, solamente se había planificado lo que sería trasmitido, en coordinación con la Caja Costarricense de Seguro Social. Sin embargo, la apertura que se logró en los medios de comunicación masiva, fue muy amplia. El apoyo de la Oficina de Divulgación de la Universidad de Costa Rica y el interés creciente del público en asuntos de nutrición, contribuyeron a esa respuesta positiva de los medios, lo que permitió una difusión mayor que la planificada y en algunos casos, de alcance nacional.

Cuñas radiales y radioteatros se trasmitieron, en forma sistemática durante dos meses, como parte de los mensajes de salud que la Caja Costarricense de Seguro Social usualmente ofrece. En esa forma fue posible la emisión de seis cuñas diarias en 15 emisoras, algunas de alcance nacional y otras de alcance regional.
A brief description of the activities carried out during Campaign implementation is presented below.

\section{a. Health and bean fair}

As a way to encourage participation, the health and bean fair not only included bean-related activities, but also activities to promote health in general. Specific activities carried out with regards to beans were: tastings of different recipes, conferences, exhibition stands, and sale of beans. There was also a display of posters made by the school children using beans.

A complementary activity carried out by the school children as an initiative from their teachers, was a homework assignment associated with beans. This was a positive experience, because it encouraged participation of children and mothers during the fair.

\section{b. Promotional stands}

This activity was implemented in the most frequently visited supermarkets by the people of Sabanilla. Clients received written and verbal information, and they had tastings of different foods prepared with beans.

\section{c. Mass media}

Due to the cost of advertising spots in mass media, the research team only planned spots that could be financed by the Caja Costarricense de Seguro Social. However, a greater mass media coverage was made possible through the support of the University of Costa Rica's Divulgation Office, and the growing public interest on nutrition issues, which allowed broader dissemination than planned and, in some cases, it even reached the whole country.

Radio and radio-play spots were systematically broadcast during two months, as part of the health messages that the Caja Costarricense de Seguro Social usually offers. In this way, it was possible to broadcast six spots daily in 15 national and regional stations.

Those same spots and radio-plays were also broadcast by other stations identified during the initial assessment as frequently viewed or heard by the target population. This was a contribution from those companies to the Campaign.

Television stations donated valuable advertising spots about the Campaign's activities, and broadcast 
Esas mismas cuñas y radioteatros se transmitieron también por algunas otras emisoras que habían sido identificadas en el diagnóstico, como de alta sintonía por parte de la población objetivo. Lo anterior fue una colaboración de esas empresas a la Campaña.

En la televisión fue posible obtener valiosos espacios gratuitos en forma de anuncios sobre actividades de la Campaña, así como entrevistas y una demostración de preparaciones con frijoles.

En los principales medios de prensa se publicaron diversos artículos resaltando el valor nutritivo de los frijoles.

\section{d. Exposición de afiches}

Seis mensajes diferentes sobre frijoles, con una ilustración alusiva, se expusieron en la comunidad por medio de afiches. Estos afiches se colocaron en lugares de gran afluencia de población (principales supermercados, la iglesia, la oficina parroquial, el correo, las farmacias y las pulperías).

\section{e. Entrega de recetarios y de desplegables}

Un recetario sobre frijoles (Dumani y Rodríguez 2000) y dos panfletos se enviaron a las madres por medio de los escolares de tercero y cuarto grados con los que se había venido trabajando. Una descripción de estos materiales se encuentra en el artículo referente al monitoreo de los materiales (Dumani y López 2004).

Adicionalmente, como respuesta a solicitudes de interesados, numerosos panfletos y recetarios se distribuyeron fuera de la comunidad de Sabanilla. Además, la principal empresa colaboradora insertó, en las bolsas que se comercializan para vender, un fascículo con recetas contenidas en el recetario ya mencionado (Oller 2001) ${ }^{5}$.

\section{f. Sesiones y otras actividades con escolares}

La mayoría de las actividades se focalizaron en los escolares de tercer y cuarto grados (grupo interactivo). Con ellos se desarrollaron charlas sobre el valor nutritivo de los frijoles; se prepararon recetas, se elaboraron carteles y se trabajó un taller de teatro.

\footnotetext{
5 Oller, J. 2001. Coordinación entre la empresa y el proyecto "Campaña Educativa para Incrementar el Consumo de frijoles". Gerente División Industrial Pedro Oller S.A. Comunicación personal.
}

some interviews and demonstrations of different bean dishes.

Some of the main media also published several articles highlighting the nutritive value of beans.

\section{d. Poster display}

Six different messages about beans, with suggestive drawings, were showed in the community, using posters. These posters were placed in much frequented places such as the main supermarkets, the church, the parish office, the post office, pharmacies, and 'pulperías' (small neighborhood grocery stores).

\section{e. Distribution of recipe books and brochures}

A recipe book about beans (Dumani and Rodríguez 2000) and two brochures were sent to the mothers through third- and fourth-grade school children participating in the Campaign. A description of these materials is in the article regarding monitoring of materials (Dumani and López 2004).

In addition, in response to requests from people who were interested, many brochures and recipe books were distributed outside of the community of Sabanilla. Furthermore, the main contributing company inserted a booklet with recipes from the recipe book mentioned above, in the bags they use to pack their products (Oller $2001)^{5}$.

\section{f. Sessions and other activities with school children}

Most of the activities were focused on third- and fourth-grade children (interactive group). Talks about the nutritive value of beans, preparation of recipes, poster making, and theater workshops were some of the activities carried out with them.

Besides, there were six different messages about beans, aimed at school children, which were shown in the schools where the Campaign was carried out.

\section{g. Sessions with support personnel}

Two sessions were held with local health personnel, where a brochure with information on beans

\footnotetext{
5 Oller, J. 2001. "Coordination between the company and the Project Educational Campaign to Increase Bean Consumption". Manager of Industrial Department Pedro Oller S.A, Personal interview.
} 
Además, seis mensajes diferentes sobre los frijoles, dirigidos a los escolares, se expusieron en las escuelas en las que se trabajó.

\section{g. Sesiones con personal de apoyo}

Con el personal local de salud se sostuvieron dos sesiones para entregar y discutir un panfleto sobre frijoles, elaborado específicamente para ese personal, que había sido previamente validado.

Una actividad no planificada inicialmente fue la información ofrecida al personal del Hospital Dr. Rafael Angel Calderón Guardia, institución que tiene a cargo el área de Sabanilla. Para este personal se organizó una mesa redonda sobre el tema: "La nutrición en la prevención y el tratamiento de enfermedades crónicas y cáncer"; en la cual se incluyó un espacio sobre los frijoles como un alimento funcional.

Con los docentes se sostuvieron reuniones de coordinación de acciones que eran también aprovechadas para ofrecer información sobre los frijoles y para entregarles material impreso.

Para las encargadas de atender los comedores y sodas escolares se organizaron tres sesiones interactivas y demostrativas, utilizando como referencia el recetario "De todo con frijoles" (Dumani y Rodríguez 2000).

También se sostuvieron reuniones de coordinación e información sobre frijoles y sobre la campaña misma con los diversos grupos comunales.

En resumen, como se observa en el esquema 2 se realizaron diferentes actividades, dirigidas a diversos actores sociales por diferentes medios. Una publicación sobre comunicación social (FAO 1996), valora el sinergismo que este tipo de intervención múltiple provoca, al lograr un impacto colectivo que es mayor que el de intervenciones separadas.

\section{h) Monitoreo}

La etapa de Ejecución incluyó también el seguimiento del proceso o monitoreo. El monitoreo cumple diversas funciones tales como: evaluación formativa, introducción de ajustes al proceso y garantía de coherencia con los objetivos (Hurtado 19996, FAO 1996). Por lo tanto es un aspecto que no debe obviarse.

6 Hurtado, 1999. Investigación cualitativa. Antropóloga e investigadora del Instituto de Nutrición de Centroamérica y Panamá (INCAP). Comunicación personal. that had been previously validated was distributed and discussed. This material was specifically made for these personnel.

Another activity that had not been initially planned, consisted in providing information to Hospital Calderón Guardia staff, a health-care institution serving the area of Sabanilla. There was a roundtable entitled "Nutrition in the prevention and treatment of chronic diseases and cancer", which was held specifically with these personnel, and it included a section about beans as a functional food.

Meetings were held with local teaching staff, in order to coordinate activities, where information and printed material about beans were also provided to them.

There were three interactive and demonstrative sessions held with the women in charge of the school lunch rooms and food stands, using the recipe book "De todo con frijoles" ("Everything with beans") as a reference (Dumani and Rodríguez 2000).

Meetings were also held with the various community groups, to coordinate and provide them with information about beans and the Campaign itself.

In summary, as may be seen in Diagram 2, various activities were carried out, aimed at different social actors using different means. A publication on social communication (FAO 1996) values the synergism generated by multiple actions, achieving a collective impact, greater than that of individual actions.

\section{h) Monitoring}

Implementation also included monitoring of the process. Monitoring fulfills several functions such as follow-up evaluation, introduction of changes to the process, and ensuring consistency with the objectives (Hurtado 19996, FAO 1996). Consequently, this aspect cannot be ignored.

As mentioned before, several findings from monitoring were used in implementation, to make changes to the plan or materials. Also, as a result of monitoring, it was possible to determine the degree of acceptance of the materials, and obtain information about aspects of particular interest for the population. Some of these results are documented in the article on monitoring (Dumani and López 2004).

\footnotetext{
6 Hurtado, 1999. Qualitative evalutation. Anthropologist/Researcher. Instituto de Nutrición de Centroamérica y Panamá (INCAP), Guatemala. Personal interview.
} 
Como ya se mencionó, varios de los hallazgos del monitoreo fueron utilizados durante la etapa de ejecución, para introducir ajustes al plan o a los materiales. También, como resultado del monitoreo, fue posible determinar el nivel de aceptación de los materiales y obtener información sobre aspectos en los que la población tenía un interés particular. Algunos de esos resultados se documentan en un artículo sobre el monitoreo realizado (Dumani y López 2004).

\section{Lecciones aprendidas}

\section{Con respecto a la Planificación:}

1. Dado que el objetivo de la campaña se circunscribía a un solo alimento, fue posible obtener una perspectiva más completa y profunda los conocimientos, actitudes y prácticas de la población con respecto al mismo. De esta manera, se contó con una rica información preliminar para el diseño de un plan de comunicación y socio-culturalmente adecuado para la población a la cual se dirigía. Este plan de comunicación permitió, a su vez, una planificación apropiada con respecto a los objetivos, los mensajes y las actividades que debían utilizarse durante la campaña.

2. El conocimiento de la comunidad, su organización social y los canales de comunicación del grupo objetivo permitieron determinar las estrategias que deberían emplearse y las actividades que podrían planificarse.

3. Puesto que en muchos casos, la educación nutricional tiene como grupo objetivo a las madres, sus posibilidades de espacios para la comunicación interpersonal, deben ser siempre determinados. Si no los hay, como en este caso, la planificación debe orientarse hacia un abordaje indirecto.

En esta campaña, la planificación utilizó estrategias alternativas para obviar las limitaciones de tiempo de las madres. Una estrategia de utilidad fue la integración a la Campaña de los grupos interactivo y de apoyo. Otro mecanismo indirecto que se utilizó con éxito fue el envío de materiales impresos y la utilización de otros medios masivos, diseñados y orientados específicamente a ellas.

La organización de actividades interactivas dirigidas a toda la comunidad también contribuyó a involucrar a las madres en el proceso educativo.

4. La relación interactiva que se estableció con la comunidad desde la etapa de diagnóstico, fue también

\section{Lessons learned}

With regards to planning:

1. Given that the Campaign's objective was limited to only one food (beans), it was possible to obtain a more comprehensive and in-depth perspective of the population's knowledge, attitudes, and practices in this regard. As a consequence, there was abundant preliminary information to design a communication plan that would be technically and socio-culturally adequate for the population at which it was aimed. At the same time, this plan permitted of an appropriate planning with regards to the objectives, the messages, and the activities to be used during the Campaign.

2. Knowing the community and its social organization, as well as the ways to reach the target group, allowed definition of strategies to use, and activities to plan.

3. Since in many cases mothers are the target group for nutritional education, possible spaces for interpersonal communication must always be determined. If like in this case there isn't any space to meet with them, planning must consider indirect ways to reach them.

In this Campaign, planning also considered alternative strategies to bridge the mothers' time limitations. A useful strategy consisted in integrating the interactive and support groups into the Campaign. Another successful indirect mechanism to reach them was the distribution of printed material specifically designed for them, and the use of other mass media directed at them.

Organization of interactive activities aimed at the community in general, also contributed to get mothers involved in the educational process.

4. The interactive relationship established with the community starting in the initial assessment was also important during planning. Exchange meetings with community members and teachers to discuss preliminary proposals contributed to improve the plan and adjust the work chronogram.

\section{With regards to implementation}

5. The instruments used, namely the matrix for the communication plan, the Campaign plan and the chronogram, were essential to coordinate activities, prepare required materials, and establish the necessary relationships to implement the Campaign. 
importante durante la planificación. Las reuniones de intercambio con líderes comunales y maestros para discutir propuestas preliminares, contribuyeron a mejorar el plan y a ajustar el cronograma de trabajo.

\section{Con respecto a la Ejecución}

5. Los instrumentos: plan de comunicación, plan de Campaña y cronograma, fueron indispensables para coordinar actividades, elaborar los materiales necesarios y establecer los nexos que requería la ejecución de la Campaña.

6. La escuela constituyó un espacio muy valioso para el trabajo con los escolares (grupo interactivo), con los docentes y con el personal a cargo del comedor y la soda escolar (parte del grupo de apoyo). La existencia de un sistema educativo con establecimientos dispersos por todo el país, permitiría contar con esa posibilidad en otras comunidades del país.

7. Los escolares de tercero y cuarto grados de la escuela, mantuvieron comunicación con sus madres con respecto a la Campaña, lo que indica que fue acertada su selección como grupo interactivo. Además, resultó logísticamente útil enviar con ellos materiales impresos e invitaciones a las madres. Sin embargo, algunos materiales no llegaron a su destino. Es conveniente, si se utiliza este medio, darle seguimiento con el apoyo de los docentes, para asegurar la recepción de todos los materiales por las madres.

8. La feria involucró numerosas actividades y fue un medio útil para establecer comunicación con la comunidad. Dentro de los mayores atractivos estuvo la degustación de preparaciones, la exposición y la venta de frijoles; lo que le brindó a los asistentes experiencias vivenciales valiosas. Por otra parte, la iniciativa de los maestros de asignar una tarea sobre el tema a los escolares, en los días previos a la feria, hizo que madres e hijos (as) investigaran al respecto y favoreció la interacción y el aprendizaje durante la misma.

Dado que esta actividad requiere de mucho esfuerzo organizacional, es importante coordinarla con los servicios de salud locales y otros actores sociales y darle una amplia divulgación.

9. Los materiales impresos fueron un valioso medio de comunicación con las madres, los niños (as) y la comunidad en general. Esta experiencia demostró que el tiempo y el esfuerzo que el diagnóstico
6. Schools provided a very valuable space to work with school children (interactive group), teaching staff, and personnel in charge of the student lunch rooms and food stands (part of the support group). The existence of an educational system with facilities throughout the country would provide the same possibility in other communities of the country.

7. Third- and fourth-grade school children maintained communication with their mothers about the Campaign, indicating that it was correct to have chosen them as the interactive group. Besides, it was logistically useful to send printed material and invitations to the mothers with them. However, some materials did not arrive to their destination. In order to ensure reception of all materials by mothers, it would be convenient to follow up on this aspect with support from teachers, if this strategy was to be used in another campaign.

8. The fair included many activities and was a useful way to establish communication with the community. Some of the greatest attractions were tastings of different bean-based preparations, and a bean demonstration and sale, giving participants valuable hands-on experiences. Furthermore, the teachers' initiative to assign children a homework on the subject some days before the fair, made mothers and children investigate, favoring interaction and learning during the fair.

Given that this activity requires a great organization effort, it is important to coordinate it with local health services and other social actors, and to make sure that it is widely publicized.

9. Printed materials constituted a valuable means to communicate with mothers, children, and the community at large. This experience showed that the time and effort invested in the initial assessment and validation resulted in materials that were accepted and understandable for the target population (Dumani and López 2004). This procedure must be followed before this type of material is produced massively, because it is usually expensive.

10. The increasing interest from the public in nutrition issues and the institutional support, create valuable opportunities for nutrition education through mass media, which are very important to reinforce the messages, and expand the reach of communication effords.

11. It is possible that a simultaneous implementation of the interactive and mass components, as it was 
y la validación demandaron, dieron como resultado materiales que fueron aceptados y comprendidos por la población (Dumani y López 2004). Se recomienda seguir este procedimiento, antes de producir en forma masiva este tipo de materiales cuyo costo es usualmente alto.

10. El interés creciente del público en asuntos de nutrición y el respaldo institucional abren espacios para la educación nutricional en los medios masivos. Estos son muy importantes para complementar los esfuerzos de comunicación interactiva, al mismo tiempo que permiten ampliar la cobertura.

11. Es posible que el desarrollo conjunto del componente interactivo y el componente masivo, tal como estaba planificado, hubiera redundado en un mayor impacto. Las limitaciones de presupuesto y de tiempo del equipo de trabajo no lo permitieron. Sin embargo, esta experiencia demostró que el monitoreo permite adaptar lo planificado a las circunstancias y continuar con el proceso.

En términos generales es importante rescatar:

12. Que los alimentos son parte integral de la vida y su uso es cotidiano. Las poblaciones tienen un amplio bagaje cultural sobre su utilización y manipulación, sobretodo si constituyen parte del patrón alimentario tradicional, como es el caso de los frijoles en nuestra cultura.

Solamente mediante un abordaje tan específico es posible obtener toda esa riqueza de información y verterla en un plan de comunicación que considere tanto el valor nutritivo del alimento, como las barreras para su consumo, los aspectos que pueden favorecerlo y el lenguaje utilizado para su manipulación. Es ilustrativo señalar que, en algunos casos, la comunicación de doble vía que se utilizó, incluso llevó a los investigadores a profundizar en la revisión bibliográfica, a fin de ofrecer respuestas científicas a planteamientos de la población. El resultado fue una planificación y una ejecución basadas en el entorno socio-cultural, ligado al conocimiento científico que podría garantizar un mayor impacto educativo que el enfoque tradicional.

13. La evaluación posterior de la campaña, demostró un incremento importante en el consumo de frijoles y efectos positivos en cuanto a conocimientos, actitudes y prácticas.

Eso refuerza nuestra premisa de que los cambios en los hábitos alimentarios, por estar tan fuertemente arraigados en el entorno socio-cultural, tie- planned, would have produced a greater impact, but budgetary and time limitations of the project did not make this possible. However, this experience proved that with monitoring it is possible to adjust the plan to the circumstances and continue with the process.

In general terms it is important to point out that:

12. Foods are an integral part of life, and they are consumed daily. Populations have a diverse cultural background about their uses and preparations, mostly if they are part of the traditional eating habits, as is the case with beans in Costa Rican culture.

The specific approach used makes it possible to obtain abundant information and traslate it into a communication plan that not only takes into account the nutritional value of a specific food, but also the barriers and aspects favoring its consumption, as well as the language used for its handling. It is illustrative that in some cases, the two-way communication used, led researchers to make an in-depth revision of the bibliography, in order to provide scientific answers to the population's concerns. The results were a plan and implementation based on the socio-cultural context that may ensure a greater educational impact than the traditional approach.

13. The evaluation made after Campaign implementation showed an important increase in bean consumption, and positive effects with regards to knowledge, attitudes, and practices.

These results confirm our premise that, since eating habits are such a fundamental part of society and culture, changes have to be made specifically, working with one or a reduced group of foods at a time, in an integrated manner, covering all aspects about that food, and using different means to reach the population.

The dispersion of the traditional approach of nutritional education based on general teachings about healthy nutrition, is so great that makes it difficult to produce the behavioral and attitudinal changes required to improve nutrition.

\section{REFERENCES}

ADRIEN, M. 1994. Social communication in nutrition: a methodology for intervention. Rome, Italy: FAO. p. 79. 
nen que abordarse de manera específica, alrededor de uno o de un grupo reducido de alimentos y al mismo tiempo de forma integral (que abarque todos los aspectos sobre el alimento y utilice diferentes medios para llegar a la población).

La dispersión del enfoque tradicional de la educación nutricional que se basa en la enseñanza de una alimentación saludable, es tan amplia, que difícilmente podría incidir en las modificaciones de conducta y de actitudes que se requieren para mejorar la alimentación.

\section{LITERATURA CITADA}

ADRIEN, M. 1994. Social communication in nutrition: a methodology for intervention. Rome, Italy: FAO. p. 79.

ALBALA, C.; VÍO, F. 2000. Obesidad y pobreza: Un desafío pendiente en chile. In: Peña, M.; Bacallao, J. La obesidad en la pobreza. Un nuevo reto para la salud pública.(N o 526). OPS/OMS. Washington D. F.: OPS. 3-11.

CAMPOS, E; FERNÁNDEZ, A; SÁNCHEZ, I; SANCHO, T.; VILLALOBOS, C. 1999. Diagnóstico para una campaña educativa para aumentar el consumo de frijol en una comunidad del área urbana de clase media. Seminario de Licenciatura. San José, Costa Rica: Universidad de Costa Rica. 153 p.

DUMANI, M. ; RODRÍGUEZ, S. 2000. De todo con frijoles. San José, Costa Rica: Universidad de Costa Rica, Escuela de Nutrición/CITA-Programa Bean Cowpea CRSP-AID. p. 35.

; LÓPEZ, E. 2004. Monitoreo de los materiales escritos y de los puestos de información de una campaña educativa para aumentar el consumo de frijoles. Agronomía Mesoamericana 15(3): 343-355.

; RODRÍGUEZ, S. 2004. Proceso para la determinación de prácticas nutricionales recomendables con respecto a los frijoles. Revista Costarricense de Salud Pública. Año $13, \mathrm{~N}^{\circ} 24: 32-38$.

FAO. 1996. Guía metodológica de comunicación social en nutrición. Roma, Italia: FAO. p. 101.

INCAP/ICNND/ Ministerio de Salubridad Pública de Costa Rica. 1969. Evaluación Nutricional de la Población de Centroamérica y Panamá: Costa Rica. Publicación INCAP-V-28. Guatemala, Guatemala: INCAP. 113 p.

MARTÍNEZ, T., MURILLO, A., PÁEZ, P.; RODRÍGUEZ, S. 2000. Elaboración de los contenidos de los mensajes de una Campaña educativa para aumentar el consumo de frijol en una comunidad del área urbana de clase media. Seminario de Licenciatura. San José, Costa Rica: Universidad de Costa Rica. 103 p.
ALBALA, C.; VÍO, F. 2000. Obesidad y pobreza: Un desafío pendiente en chile. In: Peña, M.; Bacallao, J. La obesidad en la pobreza. Un nuevo reto para la salud pública.(N o 526). OPS/OMS. Washington D. F.: OPS. 3-11.

CAMPOS, E; FERNÁNDEZ, A; SÁNCHEZ, I; SANCHO, T.; VILLALOBOS, C. 1999. Diagnóstico para una campaña educativa para aumentar el consumo de frijol en una comunidad del área urbana de clase media. Seminario de Licenciatura. San José, Costa Rica: Universidad de Costa Rica. 153 p.

DUMANI, M. ; RODRÍGUEZ, S. 2000. De todo con frijoles. San José, Costa Rica: Universidad de Costa Rica, Escuela de Nutrición/CITA-Programa Bean Cowpea CRSP-AID. p. 35.

; LÓPEZ, E. 2004. Monitoreo de los materiales escritos y de los puestos de información de una campaña educativa para aumentar el consumo de frijoles. Agronomía Mesoamericana 15(3): 343-355.

; RODRÍGUEZ, S. 2004. Proceso para la determinación de prácticas nutricionales recomendables con respecto a los frijoles. Revista Costarricense de Salud Pública. Año $13, \mathrm{~N}^{\circ} 24: 32-38$.

FAO. 1996. Guía metodológica de comunicación social en nutrición. Roma, Italia: FAO. p. 101.

INCAP/ICNND/ Ministerio de Salubridad Pública de Costa Rica. 1969. Evaluación Nutricional de la Población de Centroamérica y Panamá: Costa Rica. Publicación INCAP-V-28. Guatemala, Guatemala: INCAP. 113 p.

MARTÍNEZ, T., MURILLO, A., PÁEZ, P.; RODRÍGUEZ, S. 2000. Elaboración de los contenidos de los mensajes de una Campaña educativa para aumentar el consumo de frijol en una comunidad del área urbana de clase media. Seminario de Licenciatura. San José, Costa Rica: Universidad de Costa Rica. 103 p.

MINISTERIO DE SALUD. 1996. Encuesta Nacional de Nutrición. Fascículo 3: Consumo Aparente. San José, Costa Rica. p. 45.

MURILlO, A.; RODRÍGUEZ, S. 2004. Conocimientos, actitudes y prácticas de madres de escolares con respecto a los frijoles. Agronomía Mesoamericana 15(3): 277-289.

PÁEZ, P. ; RODRÍGUEZ, L. 2004. Plan de comunicación: un buen instrumento para que su Campaña tenga éxito. Agronomía Mesoamericana 15(3): 315-326.

PEÑA, M.; BACALLAO, T. 2000. La obesidad en la pobreza: Un problema emergente en las Américas. In: Peña, M \& Bacallao, J. La obesidad en la pobreza. Un nuevo reto para la salud pública.(N o 526). OPS/OMS. Washington D. F.: OPS; 3-11.

RODRÍGUEZ, L. 2004. El proyecto Campaña educativa para incrementar el consumo de frijoles. Agronomía Mesoamericana 15(3): 245-261. 
MINISTERIO DE SALUD. 1996. Encuesta Nacional de Nutrición: Fascículo 3 Consumo Aparente. San José, Costa Rica. p. 45.

MURILlO, A.; RODRÍGUEZ, S. 2004. Conocimientos, actitudes y prácticas de madres de escolares con respecto a los frijoles. Agronomía Mesoamericana 15(3): 277-289.

PÁEZ, P. ; RODRÍGUEZ, L. 2004. Plan de comunicación: un buen instrumento para que su Campaña tenga éxito. Agronomía Mesoamericana 15(3): 315-326.

PEÑA, M.; BACALLAO, T. 2000. La obesidad en la pobreza: Un problema emergente en las Américas. In: Peña, M \& Bacallao, J. La obesidad en la pobreza. Un nuevo reto para la salud pública.(N o 526). OPS/OMS. Washington D. F.: OPS; 3-11.

RODRÍGUEZ, L. 2004. El proyecto Campaña educativa para incrementar el consumo de frijoles. Agronomía Mesoamericana 15(3): 245-261.

; RODRÍGUEZ, S. 2003. Consumo de frijoles y atención en salud de familias de una comunidad urbana de Costa Rica. Revista Costarricense de Salud Pública, 12(23): 47-51.

RODRÍGUEZ, S.; MURILLO A. 2004. Conocimientos, actitudes y prácticas de escolares con respecto a los frijoles. Agronomía Mesoamericana 15(3): 291-300.
; RODRÍGUEZ, S. 2003. Consumo de frijoles y atención en salud de familias de una comunidad urbana de Costa Rica. Revista Costarricense de Salud Pública, 12(23): 47-51.

RODRÍGUEZ, S.; MURILLO A. 2004. Conocimientos, actitudes y prácticas de escolares con respecto a los frijoles. Agronomía Mesoamericana 15(3): 291-300. 